\title{
THE CONTENT OF LEAD, CADMIUM, CUPRUM, AND ZINC IN ANCHOVY (Stolephorus SP) AND WHITE SHRIMPS (Penaeus merguensis) IN KAO BAY OF NORTH HALMAHERA
}

\author{
Reni Tyas Asrining Pertiwi ${ }^{1}$
}

\begin{abstract}
Some researcher's claim some of fish have been studied in Kao Bay were at dangerous level because mercury and cyanide contains. Nevertheless, up to now people around Kao Bay were consumed a marine product as a livelihood sources and food sources. The purpose of this research were to determine of $\mathrm{Pb}$, $\mathrm{Cd}, \mathrm{Cu}$ and $\mathrm{Zn}$ on anchovy (Stolephorus $\mathrm{sp}$ ) and white shrimp (Penaeus marguiensis) around Kao Bay. The result expected could contributing the feasible of anchovy and white shrimp were consumed. The method were used to determine the content of $\mathrm{Pb}, \mathrm{Cd}, \mathrm{Cu}$ and $\mathrm{Zn}$ on anchovy and white shrimp by using AAS method with $\mathrm{HNO} 3$ reagent. Those research assess the content of heavy metals in laboratory of Mathematics and Science Faculty of Brawijaya University. The results obtained the metal content in anchovy were $\mathrm{Zn}>\mathrm{Cd}>\mathrm{Pb}>\mathrm{Cu}$ and the metal content in white shrimp were $\mathrm{Zn}>\mathrm{Cu}>$ $P b>C d$. The results showed the content of $P b$, $\mathrm{Cd}, \mathrm{Cu}$ and $\mathrm{Zn}$ on anchovies had exceeded the maximum limit were set and the content of $P b$, $\mathrm{Cd}$, and $\mathrm{Cu}$ on white shrimps has exceeded except the $\mathrm{Zn}$ in was below the maximum limit but is already at a critical level.
\end{abstract}

Keywords Heavy metals, Stolephorus sp, Penaeus marguiensis

Received : 19 Januari 2018

\footnotetext{
$\left.{ }^{1}\right)$ Manajemen Sumberdaya Perairan, Fakultas Perikanan dan Ilmu Kelautan, Universitas Khairun J1 Pertamina Kampus Unkhair Kelurahan Gambesi PO Box 53 Kode Pos 97719.

E-mail: renityasasrining@gmail.com
}

Accepted : 17 Februari 2018

\section{PENDAHULUAN}

Maluku Utara memiliki enam buah teluk dengan potensi sumberdaya alam yang sangat melimpah didalamnya. Teluk Kao merupakan salah satu teluk yang paling sering mendapatkan perhatian dari semua pihak. Hal ini dikarenakan di sekitar teluk tersebut terdapat kegiatan pengeksplorasian mineral emas yang dilakukan oleh PT Nusa Halmahera Mineral (NHM) sebagai pemegang kuasa penambangan dan penambangan emas tanpa izin (PETI). Kehadiran PT Nusa Halmahera Minerals (NHM) di Kabupaten Maluku Utara ketika itu, diharapkan dapat membawa pengaruh yang positif pada masyarakat sekitar tambang (Kao dan Malifut), terutama pada sektor ekonomi, pendidikan, dan kesehatan. Keberadaan tambang tersebut menjadi sumber mata pencaharian bagi masyarakat sekitar, baik pribumi maupun pendatang, serta menjadi salah satu sumber PAD yang cukup besar bagi pembangunan Kabupaten Halmahera Utara. Besarnya manfaat ekonomi yang didapatkan tidak dapat menutupi dampak negatif yang ditimbulkan bagi lingkungan dan kesehatan masyarakat yang ada di sekitarnya. Penggunaan berbagai bahan kimia seperti merkuri dan sianida dalam proses pengekstraksian emas menyumbangkan limbah bersama dengan lumpur yang dibuang di sepanjang sungai yang kemudian bermuara di laut (Simangge, 2011). 
Roda ekonomi masyarakat semenanjung Kao (Kecamatan Kao, Kecamatan Malifut dan Desa Akelamo) benar-benar bergantung dari hasil melau Sebelum beroperasinya pengeksplorasian mineral emas di Semenanjung Kao sebagian besar merupakan nelayan bagan dengan sumber mata pencaharian menangkap ikan teri. Sering waktu dengan limbah yang dihasilkan dari eksplorasi mineral emas yang dilakukan, hal ini menyumbangkan limbah pada perairan Teluk Kao. Terjadinya pencemaran air menyebabkan ekosistem perairan mengalami gangguan. Hal ini menyebabkan ikan teri yang menjadi andalan masyarakat semenanjung Kao menghilang. Serta hilangnya udang yang digunakan sebagai bahan baku pembuatan terasi pun ikut menghilang. Sumber protein lain yang menghilang yaitu kerang dan ikan yang terdapat di Sungai Kobok Pemprov (2013). Berdasarkan observasi yang dilakukan peneliti dilokasi penelitian, ikan teri dan udang tidak hilang sepenuhnya hilang tetapi masih dapat ditemukan tetapi dalam jumlah yang sangat sedikit tidak seperti dahulu sebelum ada eksplorasi mineral emas.

Berdasarkan laporan Dinas Kelautan dan Perikanan (2007) dalam Simangge (2011). menyatakan bahwa sedimen yang masuk ke laut di duga mengandung bahan pencemar logam berat dan sianida yang telah melebihi ambang batas yang diperbolehkan, sehingga daerah tersebut tidak bisa dikembangkan sebagai areal peruntukkan budidaya perikanan. Simangge (2011) menyatakan bahwa menyatakan bahwa beberapa jenis ikan yang telah diteliti di Teluk Kao dalam tingkatan membahayakan karena mengandung merkuri dan sianida. Namun demikian masyarakat sekitar Teluk Kao sampai saat ini masih memanfaatkan hasil laut sebagai sumber mata pencaharian dan sumber makanan.

Keamanan pangan saat ini mendapatkan perhatian lebih dari industri, pemerintah dan konsumen (Rodriguez, 2015). Kesehatan manusia sebagian besar ditentukkan oleh makanannya. Makanan yang disarankan harus memenuhi kebutuhan gizi, rendah akan mikroorganisme patogen, demikian juga dengan kontaminan kimia (Martí-Cid et al., 2007). Berdasarkan permasalahan yang telah dijelaskan diatas hal ini mendasari peneliti untuk mengkaji kandungan $\mathrm{Pb}$, $\mathrm{Cd}, \mathrm{Cu}$ dan $\mathrm{Zn}$ pada ikan teri dan udang putih yang terdapat diperairan Teluk Kao yang sam- pai saat ini di konsumsi oleh masyarakat sekitar Teluk Kao. Dengan mengetahui hasil kajian tersebut hal ini diharapkan dapat mengartikan tingkat keamanan ikan teri dan udang putih layak tidaknya untuk dikonsumi oleh manusia.

\section{MATERI DAN METODE}

Penelitian kandungan $\mathrm{Pb}, \mathrm{Cd}, \mathrm{Cu}$ dan $\mathrm{Zn}$ pada ikan teri (Stolephorus $s p$ ) dan udang putih $(P$. marguiensis) di Teluk Kao dilakukan pada tahun 2017, pengambilan data lapangan dan uji laboratorium dilakukan selama 4 bulan (bulan Februari sampai Mei). Lokasi pengambilan sampel ikan teri dan udang dilakukan pada sepanjang perairan sekitar Teluk Kao. Penelitian terdiri atas 3 tahapan yaitu: tahap pertama yaitu pengambilan sampel ikan teri dilapang dilakukan secara langsung dengan menggunakan lift net atau jaring angkat dan pengambilan sampel udang dengan menggunakan trammel net atau jaring kantong. Tahap kedua yaitu analisis laboratorium kandungan $\mathrm{Pb}, \mathrm{Cd}, \mathrm{Cu}$ dan $\mathrm{Zn}$ pada ikan teri dan udang putih dengan menggunakan metode AAS dengan menggunakan pereaksi $\mathrm{HNO}_{3}$ yang dilakukan di laboratorium FMIPA Kimia Universitas Brawijaya. Tahap ketiga analisis data, sampel hasil analisis laboratorium dibandingkan dengan nilai ambang batas $\mathrm{Pb}, \mathrm{Cd}, \mathrm{Cu}$ dan $\mathrm{Zn}$ yang diperbolehkan oleh aturan yang berlaku melalui studi literatur sehingga diperoleh suatu kesimpulan layak tidaknya ikan teri dan udang putih di Teluk Kao untuk dikonsumsi.

\section{HASIL DAN PEMBAHASAN}

Berikut hasil analisis uji laboratorium kandungan $\mathrm{Pb}, \mathrm{Cd}, \mathrm{Cu}$ dan $\mathrm{Zn}$ ikan teri (Stolephorus sp) dan udang putih (P. marguiensis) di Teluk Kao dapat lihat pada Tabel 1. Hasil uji laboratorium menunjukkan bahwa kandungan logam pada ikan teri $\mathrm{Zn}>\mathrm{Cd}>\mathrm{Pb}>\mathrm{Cu}$. Kandungan logam berat $\mathrm{Zn}, \mathrm{Cd}, \mathrm{Pb}$ dan $\mathrm{Cu}$ pada ikan teri yaitu $104.12,4.82,3.95$, dan $3.2 \mathrm{mg} / \mathrm{kg}$ (Tabel 1 dan Gambar 2).

Kandungan logam Zn paling tinggi yaitu 104.12 $\mathrm{mg} / \mathrm{kg}$ dibanding dengan logam lain (Gambar 


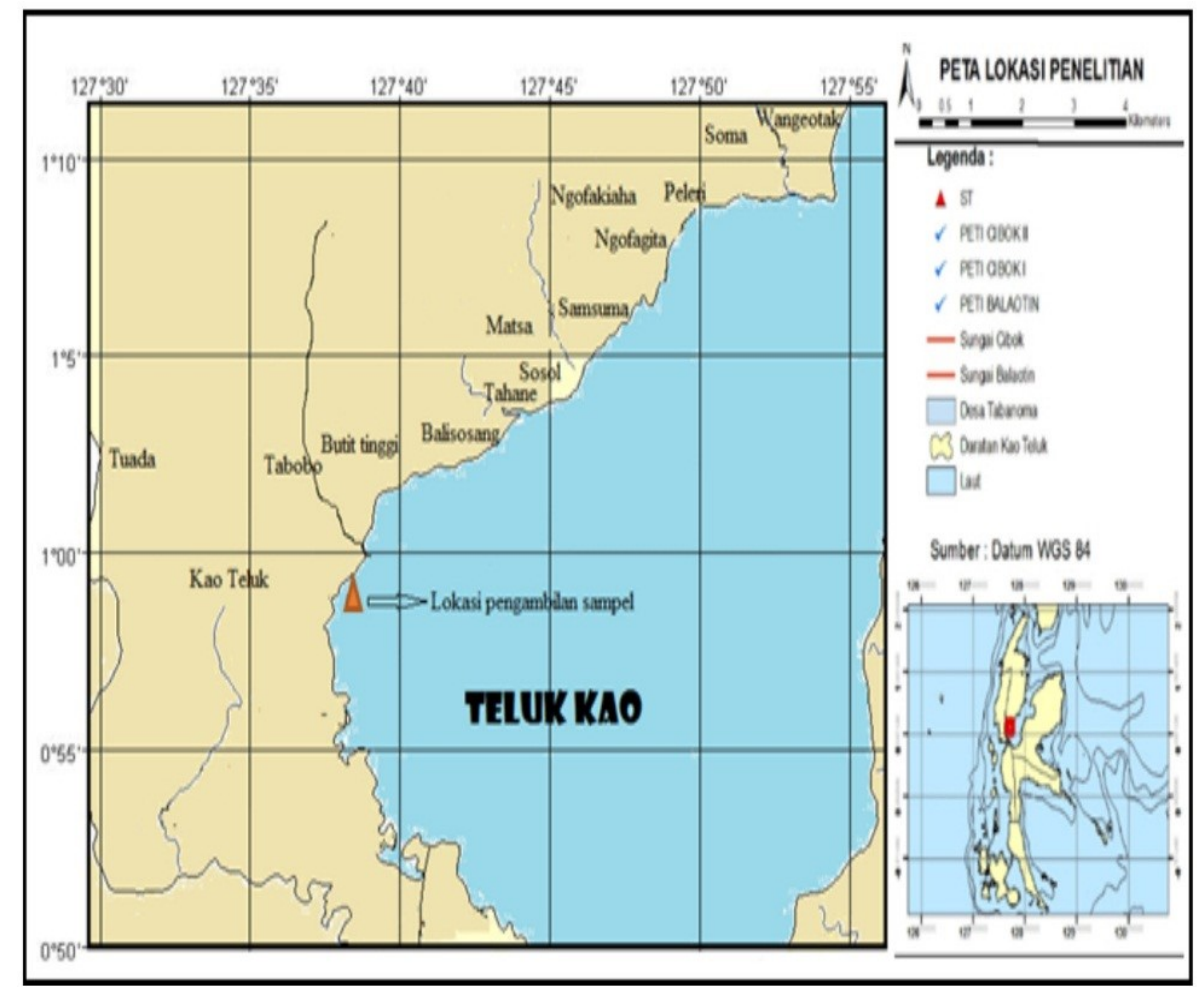

Figure 1 Peta Lokasi Pengambilan Sampel

Table 1 Hasil Analisis kandungan kandungan $\mathrm{Pb}, \mathrm{Cd}, \mathrm{Cu}$ dan $\mathrm{Zn}$ pada ikan teri (Stolephorus sp) dan udang putih ( $P$. marguiensis) di Teluk Kao

\begin{tabular}{ccccc}
\hline Logam Berat & $\begin{array}{c}\text { Ikan Teri } \\
(\mathrm{mg} / \mathrm{kg})\end{array}$ & $\begin{array}{c}\text { Udang Putih } \\
(\mathrm{mg} / \mathrm{kg})\end{array}$ & Batas maksimum ikan* & Batas maksimum udang* \\
\hline $\mathrm{Pb}$ & $3.95 \pm 0.22$ & $4.96 \pm 0.17$ & $0.3^{*}$ & $0.5^{*}$ \\
$\mathrm{Cd}$ & $4.82 \pm 0.10$ & $1.80 \pm 0.04$ & $0.1^{*}$ & $1.0^{*}$ \\
$\mathrm{Cu}$ & $3.20 \pm 0.05$ & $29.23 \pm 0.03$ & $0.3^{*}$ & $0.3^{*}$ \\
$\mathrm{Zn}$ & $104.12 \pm 0.01$ & $82.68 \pm 0.01$ & $100^{* *}$ & $100^{* *}$ \\
\hline
\end{tabular}

Ket:*) [5] **) POM, 1989 dalam [6]

2). Ini disebabkan oleh sifat logam $\mathrm{Zn}$ yang essensial bagi organisme ditambah lagi dengan banyaknya limbah yang mengandung $\mathrm{Zn}$ baik yang berasal dari tambang dan rumah tangga yang masuk ke perairan. Logam Zn memiliki batasan kadar maksimum lebih tinggi dari logam $\mathrm{Pb}, \mathrm{Cd}$ dan $\mathrm{Cu}$ karena logam berat $\mathrm{Zn}$ banyak terdapat di dalam enzim yang digunakan dalam proses metabolisme dan membantu pertumbuhan (Nurrachmi et al., 2014). Hal sebaliknya terjadi jika akumulasi logam pada tumbuhan, dimana menurut Efendi (2015) konsentrasi tertiggi adalah $\mathrm{Cu}>\mathrm{Cd}>\mathrm{Pb}$.

Kandungan Zn terdeteksi pada ikan teri melebihi batas maksimum yaitu $104.12 \mathrm{mg} / \mathrm{kg}$. Kandungan logam Zn yang diperbolehkan dalam biota laut sebesar 100 mg/kg POM, (1989) dalam

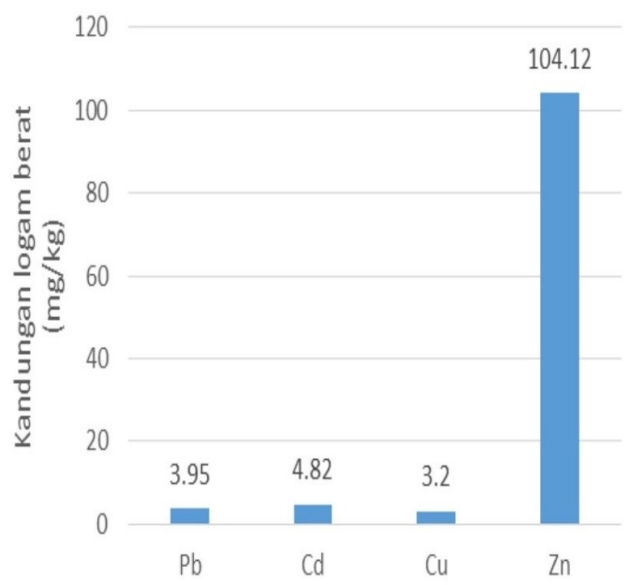

Figure 2 Kandungan logam berat dalam ikan teri (Stolephorus sp) 
Simangge (2011). Hal ini terjadi dikarenakan konsentrasi logam Zn dalam air dapat mengendap ke dasar perairan (sedimen), sehingga kandungan logam di sedimen terlarut di air yang menyebabkan kandungan logam di air tinggi Wahyuni (2013).

Konsumsi Zn berlebih dalam jangka waktu lama bisa mengakibatkan defisiensi $\mathrm{Cu}$. Total asupan $\mathrm{Zn}$ sebesar $60 \mathrm{mg}$ / hari (50 mg suplemen Zn dan $10 \mathrm{mg}$ Zn dari makanan) dapat mengakibatkan defisiensi Cu. Konsumsi Zn lebih dari $50 \mathrm{mg} /$ hari selama beberapa minggu bisa menggangu ketersediaan biologi $\mathrm{Cu}$, sedangkan konsumsi Zn yang tinggi bisa mempengaruhi sintesis ikatan $\mathrm{Cu}$ protein atau metalotionin dalam usus. Konsumsi $\mathrm{Zn}$ berlebih akan menggangu metabolisme mineral lain, khususnya Fe dan $\mathrm{Cu}$ (Widowati et al., 2008). Efek racun Zn pada manusia adalah pada konsentrasi yang tinggi antara 300 - 360 ppm, yaitu menyebabkan gangguan fisik seperti diare yang berat, keram perut dan muntah (Suprijanto and Lubis, 1988). Faktor biokonsentrasi menunjukkan bahwa plankton dapat mengakumulasi sebesar 1,221 kali lipat logam Zn yang terkandung dalam sedimen. Walaupun umur plankton jauh lebih pendek dibandingkan ikan, tetapi kemampuan mengakumulasi logam berat dalam air jauh lebih tinggi (Wahyuni et al., 2013).

Rendahnya $\mathrm{Cu}$ dalam ikan teri dapat disebabkan karena rendahnya kandungan $\mathrm{Cu}$ di air dan di sedimen. Menurut Pemprov (2013) menyatakan bahwa kandungan $\mathrm{Cu}$ dalam sedimen di Teluk Kao berkisar antara 1.414 -43.667 ppm dengan rerata 18.297 ppm. Berdasarkan Martin and Meybeck (1979) batas maksimum kandungan $\mathrm{Cu}$ dalam sedimen yaitu 45 ppm. Hal ini dapat disimpulkan bahwa kandungan $\mathrm{Cu}$ dalam perairan dan sedimen masih dibawah baku mutu yang ditetapkan. Distribusi penyerapan logam $\mathrm{Cu}$ pada ikan maksimum ditemukan pada hati, ginjal, insang dan otot. Konsetrrasi logam $\mathrm{Cu}$ pada hati sekitar sepuluh kali konsentrasi logam $\mathrm{Cu}$ pada jaringan otot (LaGrega et al., 2010). Karena uji kandungan $\mathrm{Cu}$ dilakukan pada seluruh tubuh ikan teri, hal ini menyebabkan tingginya kandungan $\mathrm{Cu}$ dalam tubuh ikan teri. Dibandingkan dengan kandungan logat berat $\mathrm{Pb}, \mathrm{Zn}$, dan $\mathrm{Cd}$, $\mathrm{Cu}$ merupakan logam berat yang sedikit ditemukan di tubuh ikan teri. Menurut Salami et al. (2008) menyatakan bahwa semakin besar kon-

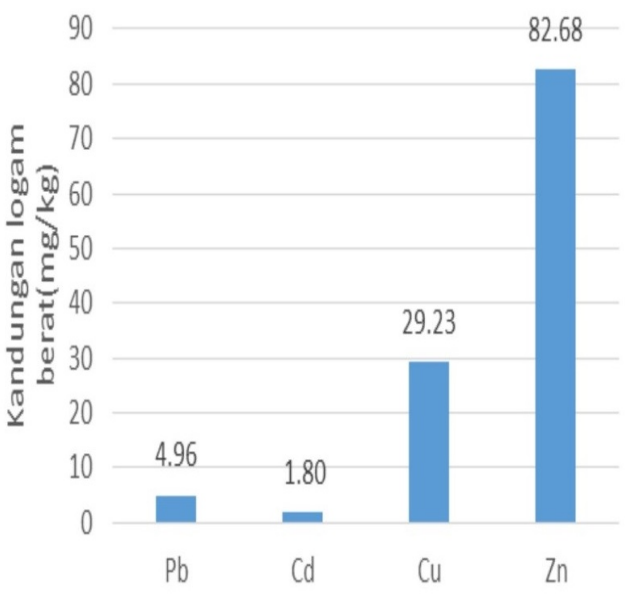

Figure 3 Kandungan logam berat dalam udang putih (Penaeus marguiensis)

sentrasi $\mathrm{Cu}$ di air semakin besar pertambahan konsentrasi $\mathrm{Cu}$ total dalam ikan. Akumulasi logam berat $\mathrm{Cu}$ terbanyak ditemukan pada hati, diikuti insang dan otot. Hati mengakumulasi logam $\mathrm{Cu}$ sampai 15-20 kali konsentrasi $\mathrm{Cu}$ pada otot.

Hasil uji laboratorium menunjukkan bahwa kandungan logam pada udang putih $\mathrm{Zn}>\mathrm{Cu}>\mathrm{Pb}>\mathrm{Cd}$. Kandungan logam berat $\mathrm{Zn}, \mathrm{Cu}, \mathrm{Pb}$ dan $\mathrm{Cd}$ pada udang putih yaitu $82.68,29.23,4.96$, dan $1.80 \mathrm{mg} / \mathrm{kg}$ (Tabel 1 dan Gambar 3). Kandungan $\mathrm{Zn}$ terdeteksi pada udang putih ( $P$. marguiensis) sebesar $82.68 \mathrm{mg} / \mathrm{kg}$ paling tinggi dibandingkan dengan kandungan logam lainnya (Gambar 3). Kandungan logam Zn yang diperbolehkan dalam biota laut sebesar $100 \mathrm{mg} / \mathrm{kg}$ (POM, 1989 dalam Blesstinov et al. (2017). Hal berarti bahwa meskipun kandungan $\mathrm{Zn}$ tinggi dalam daging udang putih ( $P$. marguiensis) namun masih di bawah batas maksimum yang telah ditetapkan yaitu $100 \mathrm{mg} / \mathrm{kg}$.

Kandungan Cd dalam daging udang putih ditemukan dalam jumlah konsentrasi yang lebih sedikit yaitu $1.80 \mathrm{mg} / \mathrm{kg}$ dibandingan logam $\mathrm{Cu}$ dan $\mathrm{Pb}$. Kandungan logam $\mathrm{Cd}$ yang diperbolehkan dalam udang sebesar $1.0 \mathrm{mg} / \mathrm{kg} \mathrm{BSN} / \mathrm{SNI}$ (2009). Meskipun kandungan Cd ditemukan dalam jumlah yang paling sedikit pada udang putih tetapi karena melebihi batas maksimum yang tetapkan yaitu $1.0 \mathrm{mg} / \mathrm{l}$, maka kandungan $\mathrm{Cd}$ dalam udang putih sudah melebihi batas maksimum. Tingginya kandungan $\mathrm{Cd}$ dalam udang putih dapat disebabkan karena banyaknya limbah pertambangan yang mengandung $\mathrm{Cd}$ pada 


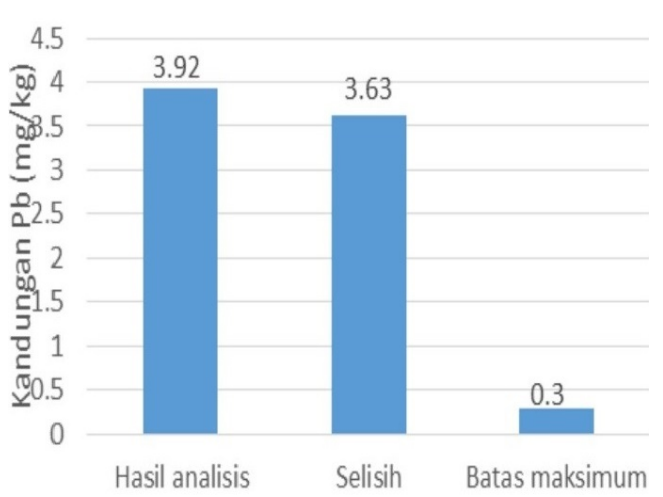

Figure 4 Kandungan $\mathrm{Pb}$ dalam ikan teri

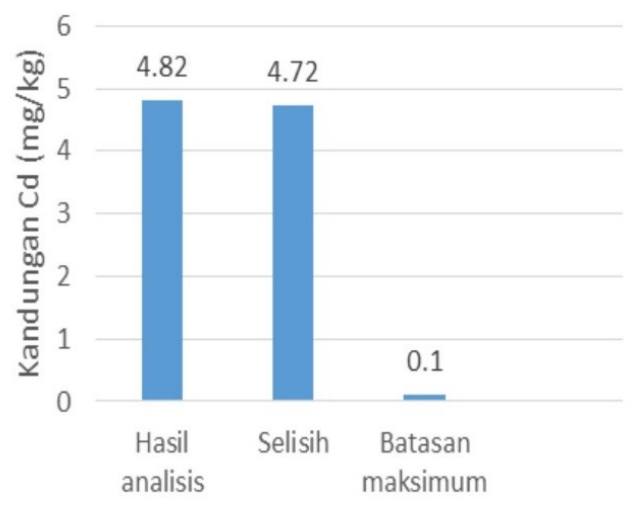

Figure 5 Kandungan Cd dalam ikan teri

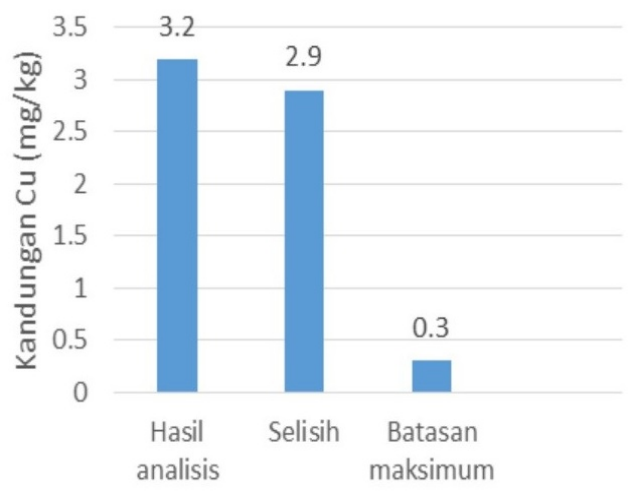

Figure 6 Kandungan Cu dalam ikan teri

air dan sedimen. Terakumulasinya $\mathrm{Cd}$ dalam udang putih melalui absorbs logam yang masuk ke dalam insang ataupun saat pergantian kulit (moulting) dan masuk ke dalam saluran pencernaan melalui aktifitas makan melalui rantai makanan serta tingginya proses pengambilan $\mathrm{Cd}$ dari perairan atau sedimen (Novianto and Raharjo, 2012).

Hasil analisis menunjukkan bahwa kandungan $\mathrm{Pb}, \mathrm{Cd}, \mathrm{Cu}$ dan $\mathrm{Zn}$ pada ikan teri telah melam-

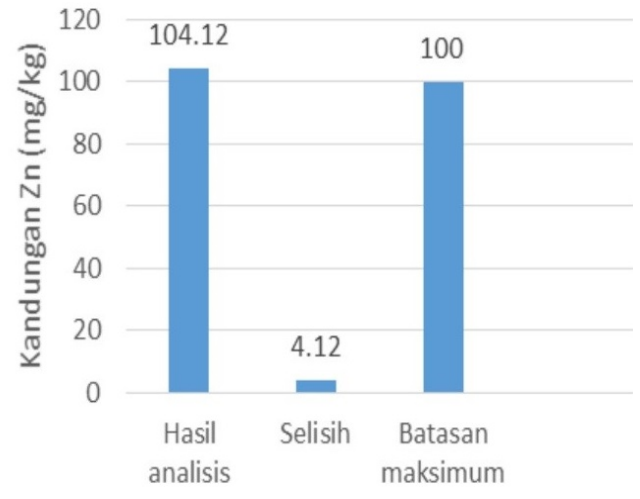

Figure 7 Kandungan Zn dalam ikan teri

paui batas maksimum yang ditetapkan (Tabel 1 dan Gambar 4, 5, 6, dan 7). Hal ini di sebabkan karena banyaknya limbah dari pertambangan yang masuk di perairan ini, terutama dari Sungai Kobok yang banyak diterima limbah serta lumpur dari wilayah hulu.

Hasil analisis menunjukkan bahwa kandungan $\mathrm{Pb}, \mathrm{Cd}$, dan $\mathrm{Cu}$ telah melampaui batas maksimum yang telah ditetapkan kecuali pada kandungan $\mathrm{Zn}$ pada udang putih masih dibawah batas maksimum yang ditetapkan (Tabel 1 dan Gambar 8,9,10, dan 11). Kandungan Zn lebih rendah dibawah batas maksimal dibandingkan dengan kandungan logam berat lainnya yaitu $\mathrm{Pb}, \mathrm{Cd}$ dan $\mathrm{Cu}$. Hal ini disebabkan karena $\mathrm{Zn}$ merupakan elemen penting dalam pertumbuhan dan metabolisme dibandingkan dengan mineral lainnya seperti $\mathrm{Pb}, \mathrm{Cd}$, dan Ni (Meshram et al., 2014). Semua bagian tubuh invertebrata memiliki kecenderungan tinggi untuk menumpuk kadar Zn yang lebih tinggi karena adanya sulfidetransporting protein dengan $\mathrm{Zn}$ pada daearh yang aktif (Flores et al., 2005) dan bertindak sebagai pendorong pertama pada semua aktifitas enzimatik (Meshram et al., 2014). Meskipun masih di bawah batas maksimal yang diperbolehkan, Zn dalam udang putih sudah mendekati batas maksimal, sehingga perlu meningkatkan kewaspadaan terhadap keamanan pangan masyarakat dari sumber udang.

\section{SIMPULAN}

Kandungan logam terutama $\mathrm{Pb}, \mathrm{Cd}, \mathrm{Cu}$ dan $\mathrm{Zn}$ pada ikan teri (Stolephorus sp) telah melebihi 


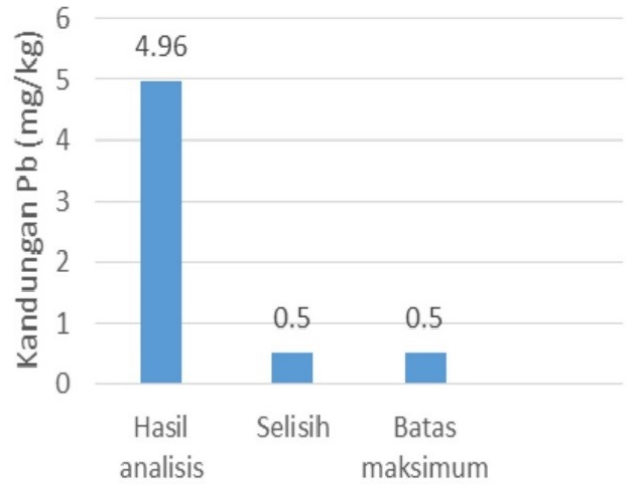

Figure 8 Kandungan $\mathrm{Pb}$ dalam udang putih

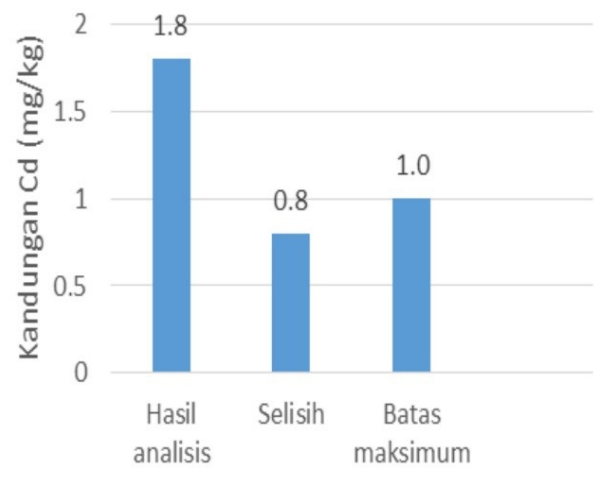

Figure 9 Kandungan Cd dalam udang putih

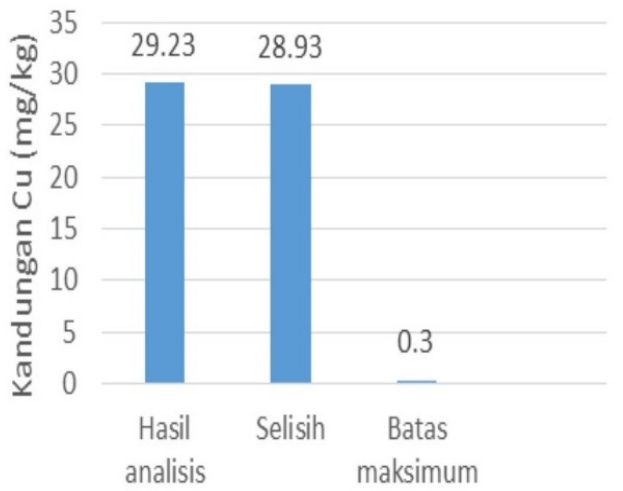

Figure 10 Kandungan $\mathrm{Cu}$ dalam udang putih

batas maksimum kandungan logam dalam pangan, sementara udang putih (P. marguensis) konsentrasi $\mathrm{Pb}, \mathrm{Cd}$ dan $\mathrm{Cu}$ telah melebihi batas maksimum kandungan logam dalam pangan. Perlunya meningkatkan kewaspadaan terhadap keamanan pangan masyarakat Teluk dari dari sumber ikan terutama ikan teri (Stolephorus $s p$ ) dan udang putih (P. marguensis).

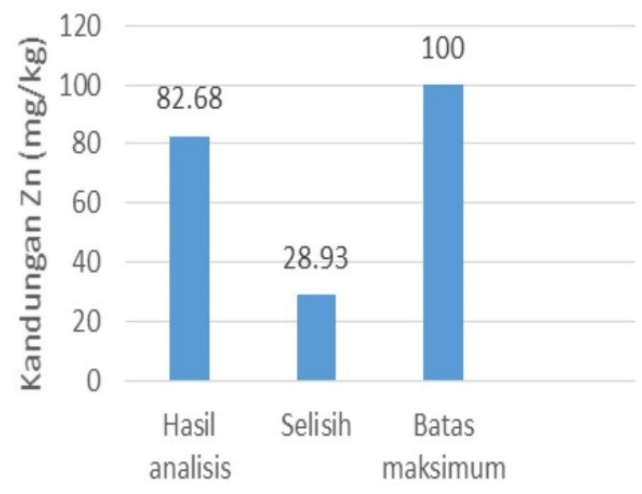

Figure 11 Kandungan $\mathrm{Zn}$ dalam udang putih

\section{References}

Blesstinov, A. G., Maddusa, S. S., and Joseph, W. B. S. (2017). Analisis kandungan seng (zn) dalam air, sedimen kerang dan ikan di sungai tondano tahun 2017. KESMAS, 6(3).

BSN/SNI (2009). Batas maksimum cemaran logam berat dalam pangan. Technical report, Badan Standar Nasional.

Efendi, E. (2015). Akumulasi logam cu, cd dan pb pada meiofauna intertitial dan epifit di ekosistem lamun monotipic (enhalus acoroides). Aquasains, 3(2):279-288.

Flores, J. F., Fisher, C. R., Carney, S. L., Green, B. N., Freytag, J. K., Schaeffer, S. W., and Royer, W. E. (2005). Sulfide binding is mediated by zinc ions discovered in the crystal structure of a hydrothermal vent tubeworm hemoglobin. Proceedings of the National Academy of Sciences of the United States of America, 102(8):27132718.

LaGrega, M. D., Buckingham, P. L., and Evans, J. C. (2010). Hazardous waste management. Waveland Press.

Martí-Cid, R., Bocio, A., Llobet, J. M., and Domingo, J. L. (2007). Intake of chemical contaminants through fish and seafood consumption by children of catalonia, spain: health risks. Food and Chemical Toxicology, 45(10):1968-1974.

Martin, J.-M. and Meybeck, M. (1979). Elemental mass-balance of material carried by major world rivers. Marine chemistry, 7(3):173-206.

Meshram, L. N., Udawant, S., Pawar, S., and Mishra, P. S. (2014). Bioaccumulation of 
heavy metals (zn, pb, cd, and ni) in tissues of penaeus monodon (fabricius, 1798) from india. Int. J. Adv. Res, 2(3):548.

Novianto, R. T. W. D. and Raharjo, F. R. (2012). Analisis kadar timbal (pb) dan kadmium (cd) pada udang putih (penaeus marguiensis) di pantai gesek sedati sidoarjo. LenteraBio, 1(2).

Nurrachmi, I., Amin, B., and Habibi, M. N. (2014). Bioakumulasi logam cd, cu, pb dan zn pada beberapa bagian tubuh ikan gulama (sciaena ruselli) dari perairan dumai, riau. Maspari Journal, 2(1):1-10.

Pemprov, M. U. (2013). Penelitian dampak penambangan emas terhadap kualitas sedimen dan kesuburan perairan di teluk kao, halmahera utara. Technical report, Stasiun Penelitian Lapangan LIPI Ternate.

Rodriguez, F. P. (2015). Food Safety. Elsevier.

Salami, I. R., Rahmawati, S., Kristijarti, A., and Yusuf, A. (2008). Pengaruh logam berat tembaga pada ikan nila (oreochromis niloticus) dan pengaruh depurasinya. Jurnal Penelitian Perikanan, 11(1):49-58Sualia.

Simangge, S. M. (2011). Analisis kandungan merkuri dan sianida pada beberapa jenis ikan hasil tangkapan nelayan di teluk kao kabupaten halmahera utara. Jurnal Agroforestri, 6(2):103-108.

Suprijanto, I. and Lubis, A. (1988). Kandungan logam berat dalam sumber air minum di dki jakarta. Buletin Penelitian Kesehatan, 16(2 Jun).

Wahyuni, H. (2013). Kandungan logam berat pada air, sedimen dan plankton di daerah penambangan masyarakat desa batu belubangkabupaten bangka tengah.

Wahyuni, H., Sasongko, S. B., and Sasongko, D. P. (2013). Konsentrasi logam berat di perairan, sedimen dan biota dengan faktor biokonsentrasinya di perairan batu belubang, kab. bangka tengah. METANA, 9(02).

Widowati, W., Sastiono, A., and Jusuf, R. (2008). Efek toksik logam: Pencegahan dan penanggulangan pencemaran. Penerbit Andi. Yogyakarta, pages 2-206. 
